\title{
QUALITY OF LIFE AND SOCIAL CHARACTERISTICS OF PATIENTS SUBMITTED TO TOTAL KNEE ARTHROPLASTY
}

\author{
Marcelo Parente Oliveira' ${ }^{1}$ Aurora Marcionila de Assunção Ferreira ${ }^{2}$, Roberta Xavier Ramos Cordeiro ${ }^{3}$, Jairo de Andrade Lima ${ }^{4}$
}

\begin{abstract}
Objective: To study the quality of life (QL) and social characteristics of patients submitted to total knee arthroplasty (TKA). Methods: The Brazilian validated version of the SF-36 Quality of Life Questionnaire was applied during the pre- and postoperative periods to assess the effect of TKA in QL. A semi-structured social questionnaire was used for the survey of patients' socioeconomic profile. Results: Some characteristics were observed in the participants' socioeconomic parameters, such as the predominance of females, age above sixty years old, family income up to three minimum salaries, patients' participation in family income, living together with other co-
\end{abstract}

habitants, educational level up to high school; and living in urban periphery housing. Regarding SF-36, there was a statistically significant rise in corresponding values in postoperative assessment when compared with the preoperative assessment in all domains. Conclusion: TKA was capable of bringing a significant improvement in quality of life. In terms of social and economic profile of this group of patients submitted to TKA, it was observed that this profile was predominantly female, aged over sixty years, with low educational level, and limited economic resources.

Keywords - Arthroplasty, Replacement, Knee; Quality of Life; Social Conditions

\section{INTRODUCTION}

Total knee arthroplasty (TKA) is a high-complexity procedure in which the aim is to relieve pain and improve function at advanced stages of degenerative joint disease, when conservative measures and other possible surgical options with less morbidity become incapable of providing satisfactory treatment ${ }^{(1-3)}$. At these stages of the disease, the consequences for the patient's general health, in its broadest view, result in in compromised quality of life ${ }^{(4-6)}$. Thus, it becomes fundamentally important to use an interdisciplinary approach towards listening to and guiding such patients, since a successful response to the surgical treatment also depends on the patients' adaptation to the preoperative and postoperative care, and their aware- ness of the objectives, risks and proposed benefits ${ }^{(1,3)}$. An interdisciplinary assessment may indicate what conditions would be satisfactory for achieving possible success in the treatment, at the different levels within each specialty ${ }^{(1)}$.

The concept of quality of life (QOL) is based on acquisition of material goods and the population's capacity to acquire them for social wellbeing. With the development of societies and the capitalist system, this term has broadened because of the need to assess the more universal context of physical, mental and social wellbeing. According to the World Health Organization (WHO), the concept of QOL most used is "the individual perception of complete physical, mental and social wellbeing"(7).

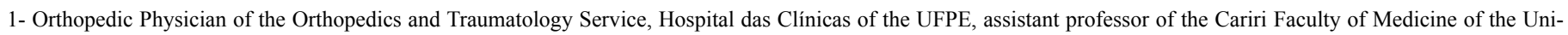
versidade Federal do Ceará, Master's degree student on the Postgraduate Program in Pathology of the CCS - Recife-PE, Brazil.

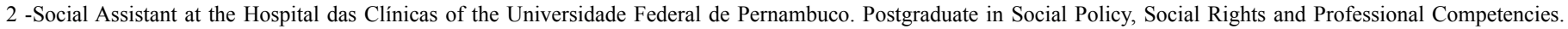
Master's degree student on the Postgraduate Program in Social Service at the Universidade Federal de Pernambuco Recife-PE, Brazil.

3 -Social Assistant at the Hospital das Clínicas of the Universidade Federal de Pernambuco. Postgraduate in Family Health Recife-PE, Brazil.

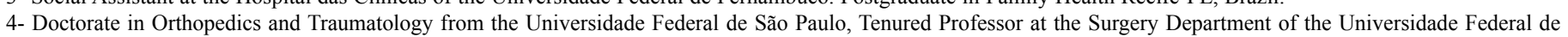
Pernambuco. Coordinator of the Orthopedics Discipline of the UFPE - Recife-PE, Brazil.

Work carried out at the Orthopedics and Traumatology Service of the Hospital das Clínicas of the Universidade Federal de Pernambuco.

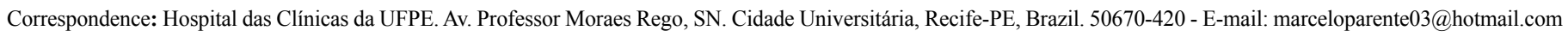
Received for publication: 04/29/2011, accepted for publication: 06/22/2011

The authors declare that there was no conflict of interest in conducting this work 
From this perspective, the role of TKA in improving QOL was examined, with a view to assessing the impact of the changes that really might interfere with the "physical, mental and social wellbeing" of patients undergoing this procedure. The aim of the study was not to focus not on the technical issues of TKA, but to consider these parameters within the subjects' universal characteristics and within the changes that the treatment will establish in their lives, in relation not only to the pain factor and the functional improvement of the knee (which have been extensively covered in the specialized literature) but also to aspects of the subjects' family, social and occupational lives.

\section{METHOD}

This study was conducted between September 2009 and November 2010, among patients at the Orthopedics and Traumatology Service of Hospital das Clínicas, Federal University of Pernambuco (HC/ UFPE). Patients with conditions of degenerative joint disease of the knee at an advanced stage who had been assessed by the interdisciplinary team and had received an indication for TKA were included.

Concomitantly, two evaluation instruments were used: the validated Brazilian version of the SF36 quality-of-life questionnaire ${ }^{(8)}$ and a semi-structured social questionnaire drawn up by the Social Service of HC/UFPE. The SF-36 QOL assessment instrument was used to analyze the data obtained through the investigation and to evaluate the results. In parallel, the social questionnaire was used with the aim of separately analyzing socioeconomic characteristics within the subjects' universe of realities. Both of these instruments were applied individually before the surgical procedure, at the time of the patients' hospital admission. The SF-36 QOL questionnaire was reapplied in the sixth month after the operation.

The SF-36 QOL questionnaire is used to ascertain patients' physical and mental health. The points given for each question are transformed into scores for eight domains, which can range from 0 to 100 , such that 0 is the worst score and 100 is the best score for each domain. The domains analyzed relate to functional capacity, limitations due to physical factors, pain, general state of health, vitality, social factors, emotional factors and mental health.

The aim was to assess all of the patients who underwent primary TKA during the study period. Every month, the Orthopedics and Traumatology Service of $\mathrm{HC} / \mathrm{UFPE}$ admits around eight patients have this procedure done, which should have produced a total of around 48 procedures during the first six months of this study, when the instruments would be applied preoperatively. However, because of factors of a structural nature within the institution, it was only possible to select a total of 23 patients. Of these, 17 underwent the proposed surgery; the remaining six patients (who did not undergo surgery), and one of the patients who underwent surgery, only had an initial assessment and therefore did not participate in the second phase of the study, which consisted of applying the QOL evaluation instruments in the sixth postoperative month. The reasons for the occurrences relating to the latter seven patients were as follows:

One of the patients who underwent the surgical procedure presented a neurological disease that impeded the quality-of-life assessment after the surgery. This patient was referred for neurological care and is being followed up;

One patient did not undergo surgery because of a reassessment by the interprofessional team, given that it was observed that the patient was not in a satisfactory psychosocial condition to undergo surgery;

Three patients did not undergo the proposed surgery after reassessment by the medical team; it was considered that because of certain clinical factors, they should be referred for another type of treatment;

Two patients did not undergo the surgery because, for structural reason relating to the institution, their operations were cancelled twice and the treatment was thus postponed.

The 16 patients who participated in both stages of the study underwent TKA and were interviewed before the operation using both assessment instruments and after the operation using the SF-36 quality-of-life questionnaire.

The data were stored and descriptive statistics were used to produce tables and the other quantitative results that are presented. To evaluate hypotheses, the Kolmogorov-Smirnov test was used to ascertain whether the distribution was normal; if the data were nonnormal, the Wilcoxon nonparametric test was used.

This study was conducted with formal voluntary consent from the patients. The consent statements were interpreted by the investigators in order to reinforce the most accessible language possible, for better understanding among the research subjects. This study was approved by the Research Ethics Committee of the Health Sciences Center of UFPE. 


\section{RESULTS}

The socioeconomic profile was constructed through identifying the socioeconomic conditions expressed in the social questionnaire, using the total of 23 patients who participated in the study, i.e. even those who did not participate in the second phase. It was observed that out of the 23 patients studied, 17 were female and six were male, with a mean age of 68.4 years (ranging from 58 to 86 years). The questions relating to marital status, schooling level, profession, social security situation, family composition, family income, housing and transportation are detailed in Table 1.

The main descriptive measurements for the variables relating to the SF-36 questionnaire, which was applied before and after the surgery among the 16 patients who participated in both stages of the study, are detailed in Table 2. We observed that in all the domains, there were statistically significant increases in the values from the postoperative assessments, in relation to the preoperative assessments, as demonstrated by the Wilcoxon nonparametric test. This test was chosen because the analyses were on two related samples (before and after) and because the hypothesis of normal distribution of the variables was rejected through the Kolmogorov-Smirnov test, in each of the domains. The p-values resulting from the Wilcoxon test led to rejection of the hypothesis of equality of means, i.e. they showed that there were significant differences between the values of all the domains, which reinforced the analysis that had been done previously.

\section{DISCUSSION}

With the development and universalization of modern knee arthroplasty, the introduction of various prosthesis models and the different methods for dealing with surgical technique issues (such as management of the posterior cruciate ligament and the femoropatellar joint), it has become fundamental to develop methods to assess the results. Within this context, the Hospital for Special Surgery Knee Score and the Knee Society Score have become the two systems that are most used ${ }^{(9)}$. Because these systems deal with TKA through the specific knee surgery results or through the functional result relating directly to the knee, they lack data providing information on the consequences of treatment for the patients' general health. In an attempt to fill this need, result evaluation systems that take into account the patients' general data have been developed. These include the Western Ontario and McMaster Universities Osteoarthritis Index (WOMAC) $)^{(5,10)}$. Clinical assessments on patients' state of health often reflect the physician's perceptions of the disease, frequently without correlations with patients' own perceptions about their health ${ }^{(11)}$.

In the light of the broader concept of QOL advocated by WHO, namely "individual perception of complete physical, mental and social wellbeing", the need arises to deal with the results from treatment within this context. Application of assessment systems directed towards objective issues relating to the therapy in question (in this case, TKA) may often provide a false impression of success in the treatment, based on simple improvement of the scores used. The contrary may also be true, i.e. an apparently poor result measured using scores may undervalue the real reach of the treatment for the patient's general health and QOL. This is particularly true for patients with multijoint degenerative disease, especially in cases of inflammatory arthritis and autoimmune diseases ${ }^{(5,11)}$. However, when the improvement in QOL is evaluated, i.e. what the treatment has effectively provided for improving the patient's life, the result may be different. Although assessment methods like WOMAC may provide information on patients' general state of health, measurements that are more appropriate for obtaining information of greater completeness on their physical, mental and social status ${ }^{(5)}$.

The positive effect of TKA on QOL has been established in some studies ${ }^{(5,6,12-15)}$. Jolles and Bogoch ${ }^{(5)}$ studied QOL after TKA among patients with juvenile rheumatoid arthritis and observed that the instruments commonly used for assessing the results following TKA did not have the capacity to gather information of importance for the patients in the group studied. They then used result assessment systems generated by the patients themselves and, in this manner, were able to quantify the patients' satisfaction and improvement in QOL after TKA, in relation to different aspects of daily life. In our study, we used the validated Brazilian version of the SF-36 quality-of-life questionnaire $^{(8)}$. It could be seen that there were statistically significant increases in all the domains of the instrument after the operation, in relation to before the operation, and it was observed that TKA contributed significantly towards improving the patients' quality of life. The component of functional capacity, for ex- 
Table 1 - Socioeconomic profile of the study participants.

\begin{tabular}{|c|c|c|c|c|c|c|c|c|c|c|c|c|c|c|c|c|c|}
\hline $\begin{array}{c}\mathrm{Pa}- \\
\text { tient }\end{array}$ & $\begin{array}{c}\text { Gen- } \\
\text { der }\end{array}$ & $\begin{array}{c}\text { Age } \\
\text { (years) }\end{array}$ & $\begin{array}{l}\text { Marital } \\
\text { status }\end{array}$ & $\begin{array}{c}\text { School- } \\
\text { ing }\end{array}$ & $\begin{array}{c}\text { Profes- } \\
\text { sion }\end{array}$ & $\begin{array}{c}\text { Social } \\
\text { security } \\
\text { situation }\end{array}$ & $\begin{array}{c}\text { Family } \\
\text { compo- } \\
\text { sition }\end{array}$ & $\begin{array}{c}\text { Family } \\
\text { income } \\
\text { (mini- } \\
\text { mum } \\
\text { sala- } \\
\text { ries) }\end{array}$ & $\begin{array}{l}\text { Fam- } \\
\text { ily income } \\
\text { sources }\end{array}$ & $\begin{array}{l}\text { Hous- } \\
\text { ing } \\
\text { status }\end{array}$ & \begin{tabular}{|c} 
Type of \\
hous- \\
ing
\end{tabular} & $\begin{array}{l}\text { Housing } \\
\text { location }\end{array}$ & $\begin{array}{c}\text { Ac- } \\
\text { cess to } \\
\text { hous- } \\
\text { ing }\end{array}$ & $\begin{array}{l}\text { Type of } \\
\text { flooring }\end{array}$ & $\begin{array}{l}\text { Water } \\
\text { supply }\end{array}$ & $\begin{array}{c}\text { Trans- } \\
\text { porta- } \\
\text { tion } \\
\text { used }\end{array}$ & $\begin{array}{c}\text { Re- } \\
\text { ceives } \\
\text { help } \\
\text { with } \\
\text { house- } \\
\text { work }\end{array}$ \\
\hline 1 & Fem & 63 & Married & $\begin{array}{c}\text { Elemen- } \\
\text { tary I }\end{array}$ & $\begin{array}{c}\text { House- } \\
\text { wife }\end{array}$ & $\begin{array}{c}\text { Depen- } \\
\text { dent }\end{array}$ & 2 people & $3 \mathrm{MS}$ & $\begin{array}{c}\text { Patient and } \\
\text { others }\end{array}$ & Owned & House & $\begin{array}{c}\text { Urban } \\
\text { periphery }\end{array}$ & Flat & Ceramic & Piped & Own car & Yes \\
\hline 2 & Fem & 61 & $\begin{array}{l}\text { Sepa- } \\
\text { rated }\end{array}$ & $\begin{array}{c}\text { Elemen- } \\
\text { tary I }\end{array}$ & $\begin{array}{c}\text { House- } \\
\text { wife }\end{array}$ & $\begin{array}{c}\text { Depen- } \\
\text { dent }\end{array}$ & 3 people & $3 \mathrm{MS}$ & Only others & Rented & House & $\begin{array}{c}\text { Urban } \\
\text { periphery }\end{array}$ & Flat & $\begin{array}{l}\text { Smooth } \\
\text { cement }\end{array}$ & Piped & $\begin{array}{l}\text { Public } \\
\text { bus }\end{array}$ & No \\
\hline 3 & Fem & 63 & $\begin{array}{l}\text { Wid- } \\
\text { owed }\end{array}$ & $\begin{array}{c}\text { Elemen- } \\
\text { tary I }\end{array}$ & $\begin{array}{c}\text { Domes- } \\
\text { tic em- } \\
\text { ployee }\end{array}$ & $\begin{array}{c}\text { Retire- } \\
\text { ment } \\
\text { pensioner }\end{array}$ & 2 people & $2 \mathrm{MS}$ & $\begin{array}{c}\text { Patient and } \\
\text { others }\end{array}$ & Owned & House & $\begin{array}{c}\text { Urban } \\
\text { periphery }\end{array}$ & Steps & Ceramic & Piped & $\begin{array}{l}\text { Public } \\
\text { bus }\end{array}$ & Yes \\
\hline 4 & Fem & 68 & Married & $\begin{array}{c}\text { Elemen- } \\
\text { tary I }\end{array}$ & $\begin{array}{l}\text { Nursing } \\
\text { auxiliary }\end{array}$ & $\begin{array}{c}\text { Retire- } \\
\text { ment } \\
\text { pensioner }\end{array}$ & 2 people & 3.5 MS & $\begin{array}{c}\text { Patient and } \\
\text { others }\end{array}$ & Rented & House & $\begin{array}{c}\text { Urban } \\
\text { periphery }\end{array}$ & Flat & Ceramic & Piped & Own car & Yes \\
\hline 5 & Male & 63 & $\begin{array}{l}\text { Living } \\
\text { to- } \\
\text { gether }\end{array}$ & $\begin{array}{c}\text { Elemen- } \\
\text { tary II }\end{array}$ & $\begin{array}{c}\text { Quality } \\
\text { inspec- } \\
\text { tor }\end{array}$ & $\begin{array}{c}\text { Retire- } \\
\text { ment } \\
\text { pensioner }\end{array}$ & 3 people & 4.5 MS & Only others & Owned & House & $\begin{array}{c}\text { Central } \\
\text { urban }\end{array}$ & Flat & Ceramic & Piped & Own car & Yes \\
\hline 6 & Fem & 63 & Single & $\begin{array}{l}\text { High } \\
\text { school }\end{array}$ & $\begin{array}{c}\text { Nursing } \\
\text { techni- } \\
\text { cian }\end{array}$ & $\begin{array}{c}\text { Retire- } \\
\text { ment } \\
\text { pensioner }\end{array}$ & 1 person & $1 \mathrm{MS}$ & Only others & Owned & House & $\begin{array}{c}\text { Urban } \\
\text { periphery }\end{array}$ & $\begin{array}{c}\text { Medium } \\
\text { slope }\end{array}$ & Ceramic & Piped & $\begin{array}{l}\text { Public } \\
\text { bus }\end{array}$ & No \\
\hline 7 & Fem & 69 & Married & $\begin{array}{c}\text { Able to } \\
\text { read }\end{array}$ & $\begin{array}{l}\text { Domes- } \\
\text { tic em- } \\
\text { ployee }\end{array}$ & $\begin{array}{c}\text { Retire- } \\
\text { ment } \\
\text { pensioner }\end{array}$ & 3 people & $2 \mathrm{MS}$ & $\begin{array}{c}\text { Patient and } \\
\text { others }\end{array}$ & Owned & House & $\begin{array}{c}\text { Urban } \\
\text { periphery }\end{array}$ & Flat & $\begin{array}{l}\text { Smooth } \\
\text { cement }\end{array}$ & Piped & $\begin{array}{l}\text { Public } \\
\text { bus }\end{array}$ & Yes \\
\hline 8 & Fem & 73 & $\begin{array}{l}\text { Wid- } \\
\text { owed }\end{array}$ & $\begin{array}{l}\text { Able to } \\
\text { read }\end{array}$ & $\begin{array}{l}\text { Seam- } \\
\text { stress }\end{array}$ & $\begin{array}{c}\text { Retire- } \\
\text { ment } \\
\text { pensioner }\end{array}$ & $\begin{array}{l}1 \text { per- } \\
\text { sona }\end{array}$ & $1 \mathrm{MS}$ & Only others & Owned & House & $\begin{array}{l}\text { Central } \\
\text { urban }\end{array}$ & Steps & $\begin{array}{l}\text { Coarse } \\
\text { cement }\end{array}$ & Piped & $\begin{array}{l}\text { Public } \\
\text { bus }\end{array}$ & No \\
\hline 9 & Fem & 73 & $\begin{array}{l}\text { Wid- } \\
\text { owed }\end{array}$ & $\begin{array}{c}\text { Able to } \\
\text { read }\end{array}$ & $\begin{array}{c}\text { Farm } \\
\text { worker }\end{array}$ & $\begin{array}{c}\text { Retire- } \\
\text { ment } \\
\text { pensioner }\end{array}$ & 2 people & $1 \mathrm{MS}$ & Only others & Owned & House & $\begin{array}{c}\text { Urban } \\
\text { periphery }\end{array}$ & Flat & Ceramic & Piped & $\begin{array}{c}\text { Family } \\
\text { car }\end{array}$ & Yes \\
\hline 10 & Fem & 69 & $\begin{array}{l}\text { Wid- } \\
\text { owed }\end{array}$ & $\begin{array}{c}\text { Elemen- } \\
\text { tary II }\end{array}$ & $\begin{array}{c}\text { House- } \\
\text { wife }\end{array}$ & $\begin{array}{c}\text { Other pen- } \\
\text { sioner }\end{array}$ & 3 people & $2 \mathrm{MS}$ & $\begin{array}{c}\text { Patient and } \\
\text { others }\end{array}$ & Owned & House & $\begin{array}{c}\text { Urban } \\
\text { periphery }\end{array}$ & Flat & Ceramic & Piped & $\begin{array}{l}\text { Public } \\
\text { bus }\end{array}$ & Yes \\
\hline 11 & Fem & 66 & $\begin{array}{l}\text { Wid- } \\
\text { owed }\end{array}$ & $\begin{array}{c}\text { Able to } \\
\text { read }\end{array}$ & $\begin{array}{c}\text { House- } \\
\text { wife }\end{array}$ & $\begin{array}{c}\text { Other pen- } \\
\text { sioner }\end{array}$ & 2 people & $2 \mathrm{MS}$ & Only others & Owned & House & $\begin{array}{c}\text { Urban } \\
\text { periphery }\end{array}$ & Flat & Ceramic & Piped & $\begin{array}{l}\text { Public } \\
\text { bus }\end{array}$ & Yes \\
\hline 12 & Fem & 79 & Single & Illiterate & $\begin{array}{c}\text { Farm } \\
\text { worker }\end{array}$ & $\begin{array}{c}\text { Retire- } \\
\text { ment } \\
\text { pensioner }\end{array}$ & 2 people & $2 \mathrm{MS}$ & Only others & Owned & House & $\begin{array}{c}\text { Urban } \\
\text { periphery }\end{array}$ & Flat & $\begin{array}{l}\text { Coarse } \\
\text { cement }\end{array}$ & Piped & $\begin{array}{l}\text { Public } \\
\text { bus }\end{array}$ & Yes \\
\hline 13 & Male & 74 & Married & $\begin{array}{c}\text { Able to } \\
\text { read }\end{array}$ & $\begin{array}{c}\text { Farm } \\
\text { worker }\end{array}$ & $\begin{array}{c}\text { Retire- } \\
\text { ment } \\
\text { pensioner }\end{array}$ & 2 people & $1.5 \mathrm{MS}$ & Only others & Owned & House & Rural & Flat & $\begin{array}{l}\text { Coarse } \\
\text { cement }\end{array}$ & $\mid \begin{array}{c}\text { Bucket/ } \\
\text { well }\end{array}$ & $\begin{array}{l}\text { Cart/ } \\
\text { similar }\end{array}$ & Yes \\
\hline 14 & Fem & 73 & Single & $\begin{array}{c}\text { Elemen- } \\
\text { tary I }\end{array}$ & $\begin{array}{c}\text { Attend- } \\
\text { ing } \\
\text { nurse }\end{array}$ & $\begin{array}{c}\text { Retire- } \\
\text { ment } \\
\text { pensioner }\end{array}$ & 1 person & $3 \mathrm{MS}$ & Only others & $\begin{array}{c}\text { As- } \\
\text { signed }\end{array}$ & House & $\begin{array}{c}\text { Central } \\
\text { urban }\end{array}$ & Flat & Ceramic & Piped & $\begin{array}{c}\text { Family } \\
\text { care }\end{array}$ & Yes \\
\hline 15 & Fem & 76 & $\begin{array}{l}\text { Wid- } \\
\text { owed }\end{array}$ & $\begin{array}{c}\text { Elemen- } \\
\text { tary I }\end{array}$ & $\begin{array}{c}\text { House- } \\
\text { wife }\end{array}$ & $\begin{array}{c}\text { Other pen- } \\
\text { sioner }\end{array}$ & 3 people & $3 \mathrm{MS}$ & $\begin{array}{c}\text { Patient and } \\
\text { others }\end{array}$ & Owned & House & $\begin{array}{c}\text { Urban } \\
\text { periphery }\end{array}$ & $\begin{array}{l}\text { Slight } \\
\text { slope }\end{array}$ & Ceramic & Piped & $\begin{array}{l}\text { Public } \\
\text { bus }\end{array}$ & Yes \\
\hline 16 & Fem & 70 & $\begin{array}{l}\text { Wid- } \\
\text { owed }\end{array}$ & Illiterate & $\begin{array}{c}\text { Farm } \\
\text { worker }\end{array}$ & $\begin{array}{c}\text { Retire- } \\
\text { ment } \\
\text { pensioner }\end{array}$ & 3 people & $3 \mathrm{MS}$ & $\begin{array}{c}\text { Patient and } \\
\text { others }\end{array}$ & Rented & House & $\begin{array}{c}\text { Urban } \\
\text { periphery }\end{array}$ & Flat & $\begin{array}{l}\text { Smooth } \\
\text { cement }\end{array}$ & Piped & $\begin{array}{l}\text { Public } \\
\text { bus }\end{array}$ & Yes \\
\hline 17 & Male & 69 & Married & $\begin{array}{l}\text { High } \\
\text { school }\end{array}$ & Driver & $\begin{array}{c}\text { Retire- } \\
\text { ment } \\
\text { pensioner }\end{array}$ & 2 people & $3 \mathrm{MS}$ & $\begin{array}{c}\text { Patient and } \\
\text { others }\end{array}$ & Owned & House & $\begin{array}{l}\text { Central } \\
\text { urban }\end{array}$ & Flat & Ceramic & Piped & Own car & Yes \\
\hline 18 & Male & 58 & $\begin{array}{c}\text { Living } \\
\text { to- } \\
\text { gether }\end{array}$ & $\begin{array}{c}\text { Elemen- } \\
\text { tary I }\end{array}$ & Driver & $\begin{array}{c}\text { Sickness } \\
\text { benefit }\end{array}$ & 5 people & $3 \mathrm{MS}$ & $\begin{array}{c}\text { Patient and } \\
\text { others }\end{array}$ & Owned & House & $\begin{array}{c}\text { Urban } \\
\text { periphery }\end{array}$ & Flat & Ceramic & Piped & $\begin{array}{l}\text { Public } \\
\text { bus }\end{array}$ & Yes \\
\hline
\end{tabular}


Table 1 - Socioeconomic profile of the study participants.

\begin{tabular}{|c|c|c|c|c|c|c|c|c|c|c|c|c|c|c|c|c|c|}
\hline 19 & Male & 76 & Married & Illiterate & $\begin{array}{c}\text { Farm } \\
\text { worker }\end{array}$ & $\begin{array}{c}\text { Retire- } \\
\text { ment } \\
\text { pensioner }\end{array}$ & 4 people & $3 \mathrm{MS}$ & $\begin{array}{c}\text { Patient and } \\
\text { others }\end{array}$ & Owned & House & $\begin{array}{c}\text { Urban } \\
\text { periphery }\end{array}$ & Flat & Ceramic & Piped & $\begin{array}{l}\text { Public } \\
\text { bus }\end{array}$ & Yes \\
\hline 20 & Fem & 58 & Single & $\begin{array}{c}\text { High } \\
\text { school }\end{array}$ & $\begin{array}{c}\text { Profes- } \\
\text { sor }\end{array}$ & $\begin{array}{c}\text { Sickness } \\
\text { benefit }\end{array}$ & 3 people & $2 \mathrm{MS}$ & $\begin{array}{c}\text { Patient and } \\
\text { others }\end{array}$ & Owned & House & $\begin{array}{c}\text { Urban } \\
\text { periphery }\end{array}$ & Flat & $\begin{array}{l}\text { Smooth } \\
\text { cement }\end{array}$ & Piped & $\begin{array}{l}\text { Public } \\
\text { bus }\end{array}$ & Yes \\
\hline 21 & Male & 59 & Married & $\begin{array}{c}\text { Elemen- } \\
\text { tary I }\end{array}$ & Baker & $\begin{array}{c}\text { Retire- } \\
\text { ment } \\
\text { pensioner }\end{array}$ & 2 people & $2 \mathrm{MS}$ & $\begin{array}{c}\text { Patient and } \\
\text { others }\end{array}$ & Owned & House & $\begin{array}{c}\text { Urban } \\
\text { periphery }\end{array}$ & Flat & Ceramic & Piped & $\begin{array}{l}\text { Public } \\
\text { bus }\end{array}$ & Yes \\
\hline 22 & Fem & 86 & $\begin{array}{l}\text { Wid- } \\
\text { owed }\end{array}$ & Illiterate & $\begin{array}{l}\text { House- } \\
\text { wife }\end{array}$ & $\begin{array}{c}\text { Other pen- } \\
\text { sioner }\end{array}$ & 5 people & $4.5 \mathrm{MS}$ & $\begin{array}{c}\text { Patient and } \\
\text { others }\end{array}$ & Owned & House & $\begin{array}{c}\text { Urban } \\
\text { periphery }\end{array}$ & Flat & Ceramic & Piped & Own car & Yes \\
\hline 23 & Fem & 65 & $\begin{array}{l}\text { Wid- } \\
\text { owed }\end{array}$ & $\begin{array}{c}\text { Able to } \\
\text { read }\end{array}$ & $\begin{array}{c}\text { House- } \\
\text { wife }\end{array}$ & $\begin{array}{c}\text { Other pen- } \\
\text { sioner }\end{array}$ & 3 people & $2 \mathrm{MS}$ & $\begin{array}{c}\text { Patient and } \\
\text { others }\end{array}$ & Rented & House & $\begin{array}{c}\text { Urban } \\
\text { periphery }\end{array}$ & Steps & $\begin{array}{l}\text { Smooth } \\
\text { cement }\end{array}$ & Piped & $\begin{array}{l}\text { Public } \\
\text { bus }\end{array}$ & Yes \\
\hline
\end{tabular}

Table 2 - Descriptive measurements for each domain relating to the SF-36 quality-of-life questionnaire before and after the surgery.

\begin{tabular}{|c|c|c|c|c|c|c|c|c|c|c|c|c|c|}
\hline \multirow[t]{2}{*}{ Domain } & \multicolumn{2}{|c|}{$\begin{array}{l}\text { Number of } \\
\text { patients }\end{array}$} & \multicolumn{2}{|c|}{ Minimum score } & \multicolumn{2}{|c|}{ Maximum score } & \multicolumn{2}{|c|}{ Median } & \multicolumn{2}{|c|}{ Mean } & \multirow[t]{2}{*}{\begin{tabular}{|l} 
p-value from \\
Wilcoxon test
\end{tabular}} & \multicolumn{2}{|c|}{$\begin{array}{l}\text { Coefficient of } \\
\text { variation }\end{array}$} \\
\hline & Before & After & Before & After & Before & After & Before & After & Before & After & & Before & After \\
\hline Functional capacity & 16 & 16 & 0.00 & 15.00 & 55.00 & 80.00 & 15.00 & 62.50 & 14.06 & 59.06 & 0.00 & 1.03 & 0.30 \\
\hline $\begin{array}{l}\text { Limitation due to physical } \\
\text { factors }\end{array}$ & 16 & 16 & 0.00 & 0.00 & 50.00 & 100.00 & 0.00 & 62.50 & 7.81 & 54.69 & 0.00 & 2.25 & 0.63 \\
\hline Pain & 16 & 16 & 20.00 & 31.00 & 61.00 & 84.00 & 35.50 & 62.00 & 35.44 & 63.00 & 0.00 & 0.38 & 0.26 \\
\hline General state of health & 16 & 16 & 30.00 & 52.00 & 87.00 & 92.00 & 67.00 & 77.00 & 64.13 & 77.31 & 0.01 & 0.26 & 0.15 \\
\hline Vitality & 16 & 16 & 25.00 & 35.00 & 80.00 & 85.00 & 62.50 & 80.00 & 59.06 & 77.33 & 0.01 & 0.28 & 0.16 \\
\hline Social factors & 16 & 16 & 12.50 & 25.00 & 87.50 & 100.00 & 37.50 & 87.50 & 40.63 & 81.25 & 0.00 & 0.48 & 0.26 \\
\hline $\begin{array}{l}\text { Limitation due to emotional } \\
\text { factors }\end{array}$ & 16 & 16 & 0.00 & 0.00 & 66.67 & 100.00 & 33.33 & 66.67 & 22.92 & 70.83 & 0.00 & 1.02 & 0.48 \\
\hline Mental health & 16 & 16 & 24.00 & 48.00 & 96.00 & 96.00 & 58.00 & 88.00 & 60.75 & 85.00 & 0.01 & 0.36 & 0.14 \\
\hline
\end{tabular}

ample, ranged from zero to 55 before the operation, with a mean of 14.06 , and $50 \%$ of the patients evaluated presented values of up to 15 . After the operation, the range was from 15 to 80 , with a mean of 59.06, and $50 \%$ of the patients evaluated presented values of up to 62.5. In addition, in all the domains, the coefficients of variation after the surgery were smaller than they had been before the surgery, thus indicating that the values before the surgery were more dispersed. Consequently, the preoperative mean was less representative than the values after the surgery.

In relation to the domain of limitations due to physical factors, the maximum value after the surgery was twice the maximum before the surgery. Half of the patients obtained a score of zero for this domain before the surgery, whereas after the surgery, it increased to 62.5. There was also an increase in the mean, from 7.81 to 54.69. However, the domain that had the biggest mean increase was the emotional factors, which had a mean of 22.92 and increased to 70.83 . On the other hand, the domain with the smallest increase was the general state of health, which went from 64.13 to 77.31 .

In relation to the socioeconomic profile, it was seen to be important to characterize the social realities of the patients who underwent TKA, thereby coming closer to the locus of their day-to-day activities that included QOL-defining situations, within the minimum perspectives that might or might not enable treatment success. This would entail absence of physical limitations and pain and provide reintroduction of the patient's activities and socialization of his environment. Furthermore, it would provide knowledge of the characteristics of the subjects involved in the study, through correlation of factors that could be considered to be important for the profile of patients who commonly undergo TKA, thus indicating issues that might interfere considerably in the results from treatment. Some studies have indicated that socioeconomic status could strongly influence the treatment of osteoarthrosis ${ }^{(4,16-18)}$. Issues such as dependence on social and/or social security benefits or unfavorable socioeconomic condition have been implicated 
in greater difficulty of access to $\mathrm{TKA}^{(16-18)}$. On the other hand, studies have indicated that the greater the time spent in a waiting list for arthroplasty, the greater the progression of the pain and physical incapacity will be ${ }^{(4)}$. It has also been shown that pain and physical incapacity before the operation are predictors of a worse result from $\mathrm{TKA}^{(19,20)}$.

Among the patients studied, certain general characteristics within the universe of the investigated subjects could be noted, such as predominance of female gender, age greater than 60 years, family income of up to three minimum salaries, participation of the patient in the source of family income, living together with other members of the family, schooling that did not go beyond high school level and a housing location on the urban periphery. These data were not crosscorrelated to identify any associations between these characteristics and the pre and postoperative QOL parameters. Ackerman et $a l^{(4)}$ reported that women and patients with worse socioeconomic conditions presented worse QOL, but this hypothesis was not tested in our study.

\section{CONCLUSION}

Among the patients studied, it was observed that TKA, as a treatment method for degenerative arthrosis of the knee at advanced stages, was capable of providing a significant improvement in quality of life.

The results from the socioeconomic questionnaire demonstrated the profile of social and economic realities of this group of patients undergoing TKA: predominance of female gender with age greater than 60 years, low schooling level and limited economic resources.

\section{REFERENCES}

1. Leme LEG, Kitadai FT, Amatuzzi MM. Artropatias degenerativas do joelho no idoso. In: Amatuzzi MM. Joelho - Articulação central dos membros inferiores. São Paulo: Roca; 2004. p. 469-78.

2. Harkess JW, Daniels AU. Artroplastia - Introdução e visão geral. In: Canale T. Cirurgia ortopédica de Campbell. Tradução e revisão científica de Alexandre David. Barueri: Manole; 2006. p. 223-242.

3. Crockarell JR, Guyton JL. Artroplastia de tornozelo e joelho. In: Canale T. Cirurgia ortopédica de Campbell. Tradução e revisão científica de José FM Alloza, Joicemar T Amaro e Idemar M Palma. Barueri: Manole; 2006. p. 243-313.

4. Ackerman IN, Graves SE, Wicks IP, Bennell KL, Osborne RH. Severely compromised quality of life in women and those of lower socioeconomic status waiting for joint replacement surgery. Arthritis Rheum. 2005;53(5):653-8.

5. Jolles BM, Bogoch ER. Quality of life after TKA for patients with juvenile rheumatoid arthritis. Clin Orthop Relat Res. 2008;466(1):167-78.

6. Horn CC, Oliveira SG. Qualidade de vida pós-artroplastia total de joelho. Rev Bras Ciênc. Envelh Hum. 2005;2(2):57-64.

7. Seidi EMF, Zannon CMLC. Qualidade de Vida e Saúde: aspectos conceituais e metodológicos. Cad. Saúde Pública 2004;20(2):580-8.

8. Miguel EC, Rosário-Campos MC, Mathis MA, Mathis ME, Lopes AC, Diniz JB, et al. Protocolo de Pesquisa do PROTOC. Departamento de Psiquiatria da Faculdade de Medicina da Universidade de São Paulo. São Paulo, Versão 2007.

9. Ghanem E, Pawasarat I, Lindsay A, May L, Azzam K, Joshi A, et al. Limitations of the Knee Society Score in evaluating outcomes following revision total knee arthroplasty. J Bone Joint Surg Am. 2010;92(14):2445-51.

10. McConnell S, Kolopack P, Davis AM. The Western Ontario and McMaster Universities Osteoarthritis Index (WOMAC): a review of its utility and measurement properties. Arthritis Rheum. 2001;45(5):453-61.
11. Wright JG, Young NL. The patient-specific index: asking patients what they want. J Bone Joint Surg Am. 1997;79(7):974-83.

12. Räsänen $P$, Paavolainen $P$, Sintonen $H$, Koivisto AM, Blom M, Ryynänen $O P$, et al. Effectiveness of hip or knee replacement surgery in terms of quality-adjusted life years and costs. Acta Orthop. 2007;78(1):108-15.

13. Rissanen $P$, Aro S, Slätis $P$, Sintonen $H$, Paavolainen P. Health and quality of life before and after hip or knee arthroplasty. J Arthroplasty. 1995;10(2):169-75.

14. Rissanen P, Aro S, Sintonen H, Slätis P, Paavolainen P. Quality of life and functional ability in hip and knee replacements: a prospective study. Qual Life Res. 1996;5(1):56-64.

15. Norman-Taylor FH, Palmer CR, Villar RN. Quality-of-life improvement compared after hip and knee replacement. J Bone Joint Surg Br. 1996;78(1):74-7.

16. Yong PF, Milner PC, Payne JN, Lewis PA, Jennison C. Inequalities in access to knee joint replacements for people in need. Ann Rheum Dis. 2004;63(11):1483-9.

17. Dixon T, Shaw M, Ebrahim S, Dieppe P. Trends in hip and knee joint replacement: socioeconomic inequalities and projections of need. Ann Rheum Dis. 2004;63(7):825-30

18. Hawker GA. The quest for explanations for race/ethnic disparity in rates of use of total joint arthroplasty. J Rheumatol. 2004;31(9):1683-5.

19. Ostendorf M, Buskens E, van Stel H, Schrijvers A, Marting L, Dhert W, et al. Waiting for total hip arthroplasty: avoidable loss in quality time and preventable deterioration. J Arthroplasty. 2004;19(3):302-9.

20. Fortin PR, Penrod JR, Clarke AE, St-Pierre Y, Joseph L, Bélisle P, et al. Timing of total joint replacement affects clinical outcomes among patients with osteoarthritis of the hip or knee. Arthritis Rheum. 2002;46(12):33 